ISSN: 2302-8556

\title{
Pengaruh Profitabilitas, Leverage dan Kepemilikan Asing Pada Pengungkapan CSR dengan Ukuran Perusahaan Sebagai Variabel Moderasi
}

\author{
Kadek Nitya Devi Irmayanti ${ }^{1}$ \\ Ni Putu Sri Harta Mimba ${ }^{2}$ \\ ${ }^{1}$ Fakultas Ekonomi dan Bisnis Universitas Udayana (Unud), Bali, Indonesia \\ email: deviirmayanti58@gmail.com/ telp: +62 83117715117 \\ ${ }^{2}$ Fakultas Ekonomi dan Bisnis Universitas Udayana (Unud), Bali, Indonesia
}

\begin{abstract}
ABSTRAK
Penelitian ini berfokus pada perusahaan consumer goods, dimana perusahaan ini memproduksi barang-barang konsumsi yang dibutuhkan secara rutin oleh masyarakat. Penelitian mengenai pengungkapan CSR pada perusahaan consumer goods masih jarang dilakukan. Sampel yang didapatkan sebanyak 7 perusahaan menggunakan teknik purposive sampling, dengan teknik analisis data yang digunakan adalah Moderated Regression Analysis (MRA). Hasil penelitian ini menunjukkan bahwa profitabilitas tidak berpengaruh signifikan pada pengungkapan CSR, leverage berpengaruh positif pada pengungkapan CSR, kepemilikan asing tidak berpengaruh signifikan pada pengungkapan CSR, ukuran perusahaan tidak mampu memoderasi pengaruh profitabilitas pada pengungkapan CSR, ukuran perusahaan mampu memoderasi (memperlemah) pengaruh leverage pada pengungkapan CSR dan ukuran perusahaan tidak mampu memoderasi pengaruh kepemilikan asing pada pengungkapan CSR.

Kata kunci: Profitabilitas, leverage, kepemilikan asing, ukuran perusahaan, pengungkapan CSR, consumer goods.
\end{abstract}

\begin{abstract}
This study focuses on consumer goods companies, there companies produce consumer goods that are routinely needed by the community. Study about CSR disclosure in this are has not many developed yet. The sample are 7 companies with purposive sampling technique. Analysis technique used is Moderated Regression Analysis (MRA). The results of this study indicate that profitability has no significant effect on CSR disclosure; leverage has a positive effect on CSR disclosure; foreign ownership has no significant effect on CSR disclosure; firm size cannot moderate the effect of profitability on CSR disclosure; firm size can moderate (i.e. weaken) leverage effect on CSR disclosures and firm size cannot moderate the effect of foreign ownership on CSR disclosure.

Keywords: Profitability, leverage, foreign ownership, CSR disclosure, firm size, consumer goods.
\end{abstract}

\section{PENDAHULUAN}

Perusahaan adalah organisasi yang mempunyai berbagai tujuan. Salah satu tujuan utama didirikannya sebuah perusahaan adalah mendapatkan profit yang tinggi. Profit yang tinggi tidak hanya didapat dari baiknya kinerja perusahaan, tetapi ada faktor-faktor lain yang berperan besar dalam memperoleh profit tersebut. Semakin 
Kadek Nitya Devi Irmayanti dan Ni Putu Sri Harta Mimba. Pengaruh...

berkembangnya teknologi, membuat persaingan diantara perusahaan akan semakin ketat. Semakin berkembangnya sebuah perusahaan, maka keberlangsungan jangka panjangnya akan semakin bergantung pada seberapa baiknya kinerja perusahaan. Kinerja perusahaan tidak hanya melihat dari sisi kinerja keuangannya saja, akan tetapi bagaimana perusahaan itu mampu memberikan kontribusi positif pada lingkungan hidup dan lingkungan sosialnya (Aghashahi et al., 2013).

Keberlangsungan lingkungan menjadi hal yang disorot banyak pihak akibat kerap terabaikannya kondisi lingkungan oleh perusahaan. Timbulnya kesadaran publik terhadap pentingnya peranan perusahaan di tengah-tengah masyarakat melahirkan kritik, karena keberadaan perusahaan dianggap dapat menciptakan masalah-masalah seperti masalah sosial, polusi, sumber daya, limbah, mutu produk, hak dan status tenaga kerja serta tingkat safety produk, (Gray et al.,1987). Perusahaan dalam menjaga kelangsungan hidup jangka panjangnya bergantung pada penilaian masyarakat mengenai tanggung jawab sosial yang dilakukan oleh perusahaan.

Tanggung jawab sosial atau yang disebut dengan corporate social responsibility (CSR) adalah suatu bentuk tanggung jawab yang dilakukan oleh perusahaan akibat dampak dari berdirinya perusahaan tersebut. CSR adalah sebuah komitmen perusahaan yang menitikberatkan pada pengembangan etika dan praktik bisnis yang sustainable atau berkesinambungan baik secara ekonomi, sosial maupun lingkungan. CSR pertama kali diperkenalkan oleh Bowen (1953) 
dengan judul buku Social Responsibility of the Businessman (Prihatiningtias dkk.,2014).

Pelaporan CSR di Indonesia, telah terkandung dalam Pernyataan Standar Akuntansi Keuangan (PSAK) No.1 Tahun 2013 tentang Penyajian Laporan Keuangan yang menyatakan: "Perusahaan dapat pula menyajikan laporan tambahan seperti laporan mengenai lingkungan hidup dan laporan nilai tambah (value added statement), khususnya bagi industri dimana faktor-faktor lingkungan hidup memegang peranan penting dan bagi industri yang menganggap pegawai sebagai kelompok pengguna laporan yang memegang peranan penting”. Selain itu CSR juga diatur dalam Undang-Undang yaitu UU No. 40 Tahun 2007 tentang Perseroan Terbatas, pasal 74 ayat (1) serta UU No. 32 Tahun 2009 tentang Perlindungan dan Pengelolaan Lingkungan Hidup. Selain itu, Perseoran yang kegiatan usahanya di bidang atau berkaitan dengan sumber daya alam diwajibkan untuk melaksanakan pengungkapan tanggung jawab sosial dan lingkungan, yang terkandung dalam Peraturan Pemerintah Republik Indonesia Nomor 47 Tahun 2012 mengenai Tanggung Jawab Sosial dan Lingkungan Perseroan Terbatas. Segala jenis kegiatan yang menyangkut kewajiban tanggung jawab sosial dan lingkungan tersebut harus diperhitungkan serta dianggarkan sebagai biaya perseroan yang dilaksanakan berdasarkan kepatutan dan kewajaran.

Perusahaan consumer goods merupakan perusahaan yang memproduksi barang-barang konsumsi yang selalu dibutuhkan dan dikonsumsi secara terus menerus oleh masyarakat. Perusahaan consumer goods merupakan perusahaan yang paling dekat dengan kehidupan sehari-hari, karena produk yang dihasilkan 
Kadek Nitya Devi Irmayanti dan Ni Putu Sri Harta Mimba. Pengaruh...

oleh perusahaan consumer goods banyak dikonsumsi oleh masyarakat. Perusahaan consumer goods mencakup lima subsektor industri yaitu industri rokok, makanan dan minuman, kosmetik, farmasi dan peralatan rumah tangga. Perusahaan consumer goods merupakan salah satu bentuk kegiatan produksi, yang mengolah sumber daya alam menjadi barang dan jasa bagi masyarakat yang bertujuan agar dapat memuaskan segala kebutuhan masyarakat serta memperoleh keuntungan (Kusumawardani, 2017). Maka dari itu, perlu diperhatikan masalah pengungkapan CSR yang dilakukannya untuk menghindari penyalahgunaan, seperti penambahan zat-zat berbahaya dalam proses produksi maupun pemakaian zat formalin dalam proses pengawetan atau bahkan menjual kembali produk yang sudah tidak layak konsumsi atau kadaluarsa (Putra, 2015).

Tingginya tingkat profitabilitas menunjukkan ketersediaan dana yang lebih untuk melaksanakan dan mengungkapkan CSR. Berdasarkan teori stakeholder, semakin tinggi profit perusahaan, maka semakin tinggi pula pengungkapan CSR yang dilakukan karena ini sebagai salah satu bukti akuntabilitas perusahaan kepada stakeholder-nya dan meyakinkan masyarakat bahwa aktivitas yang dilakukan perusahaan sudah sesuai dengan nilai sosial dan norma yang berlaku (Nugroho dan Yulianto, 2015). Hasil penelitian sebelumnya yaitu Prakasa dan Astika (2017) menyatakan bahwa profitabilitas berpengaruh positif terhadap pengungkapan CSR. Yanti dan Budiasih (2016) juga menyatakan profitabilitas memiliki pengaruh positif pada pengungkapan CSR. Dilihat dari urain tersebut, dapat disimpulkan hipotesis pertama yang diuji pada penelitian ini yaitu:

$\mathrm{H}_{1} \quad$ : Profitabilitas berpengaruh positif pada pengungkapan CSR. 
Leverage yang tinggi jika dikaitkan dengan teori stakeholder akan mengungkapkan lebih banyak informasi, karena tanggung jawab perusahaan terhadap para stakeholder-nya seperti kreditur dan investor akan lebih besar sehingga mempermudah dalam permodalannya serta menghilangkan keraguan pemegang obligasi terhadap hak mereka sebagai kreditur. Hasil penelitian sebelumnya yaitu Yanti dan Budiasih (2016) juga mendapatkan hasil yang sejalan dengan penelitian ini yaitu leverage memiliki pengaruh positif pada pengungkapan CSR. Dilihat dari urain tersebut, dapat disimpulkan hipotesis kedua yang diuji pada penelitian ini yaitu:

$\mathrm{H}_{2} \quad$ : Leverage berpengaruh positif pada pengungkapan CSR.

Kepemilikan asing merupakan sejumlah saham yang dimiliki oleh investor asing pada sebuah perusahaan, baik perorangan maupun lembaga. Besarnya kepemilikan asing di dalam sebuah perusahaan akan mampu mendorong dan memotivasi manajemen untuk lebih memperhatikan segala keinginan dan kebutuhan stakeholder-nya agar perusahaan tersebut melakukan dan mengimplementasikan pengungkapan CSR. Pengungkapan CSR merupakan salah satu penerapan dari asas tanggung jawab (responsibility) atas segala aktivitas usaha yang dilakukan perusahaan yang memberikan pengaruh pada aspek sosial dan lingkungan di sekitarny, serta mengungkapkan ke publik, sehingga hal ini akan dapat meyakinkan stakeholders bahwa aktivitas yang dilakukan perusahaan telah berjalan sesuai dengan nilai sosial dan norma yang berlaku di masyarakat, sehingga pada akhirnya akan memberikan keuntungan berupa terjaminnya keberlangsungan hidup jangka panjang perusahaan (Nugroho dan Yulianto, 2015). 
Kadek Nitya Devi Irmayanti dan Ni Putu Sri Harta Mimba. Pengaruh...

Hasil penelitian sebelumnya yang dilakukan oleh Dewi dan Suaryana (2015) serta Isa dan Muhamad (2015), menyatakan bahwa kepemilikan asing memiliki pengaruh positif pada pengungkapan Corporate Social Responsibility (CSR). Dilihat dari urain tersebut, dapat disimpulkan hipotesis ketiga yang diuji pada penelitian ini yaitu:

$\mathrm{H}_{3} \quad$ : Kepemilikan asing berpengaruh positif pada pengungkapan CSR.

Perusahaan dengan tingkat profitabilitas baik akan mengungkapkan informasi lebih rinci termasuk mempertanggungjawabkan seluruh kegiatan sosialnya (Sudjana, 2017). Teori legitimasi menyatakan, perusahaan dengan ukuran yang besar akan melakukan pengungkapan CSR untuk memperoleh legitimasi dari para stakeholder, hal ini dikarenakan perusahaan dengan ukuran yang besar akan melakukan kegiatan usaha yang lebih banyak, sehingga akan berdampak besar pula bagi masyarakat dan lingkungan sekitarnya (Yuliawati dan Sukirman, 2015). Sebuah perusahaan dengan ukuran yang besar akan terus termotivasi untuk melakukan kegiatan CSR, sehingga pihak manajemen melakukan pengawasan dan mengevaluasi kembali pelaksanaan serta pengungkapan CSR. Dilihat dari urain tersebut, dapat disimpulkan hipotesis keempat yang diuji pada penelitian ini yaitu:

$\mathrm{H}_{4}$ :Ukuran perusahaan dapat memoderasi pengaruh profitabilitas pada pengungkapan CSR

Berdasarkan teori stakeholder, rasio leverage yang lebih tinggi akan mengungkapkan lebih banyak informasi, karena tanggung jawab perusahaan terhadap para stakeholder-nya seperti kreditur dan investor akan lebih besar sehingga mempermudah dalam permodalannya. Oleh karena itu, perusahaan 
dengan rasio leverage yang tinggi akan berusaha melaksanakan CSR lebih besar untuk memberikan kepercayaan terhadap para stakeholder-nya. Perusahaan besar akan termotivasi untuk terus melaksanakan pengungkapan CSR, sehingga pihak manajemen akan melakukan pengawasan terhadap pelaksanaan dan pengungkapan CSR yang telah dilaksanakan. Dilihat dari urain tersebut, dapat disimpulkan hipotesis kelima yang diuji pada penelitian ini yaitu:

$\mathrm{H}_{5}$ :Ukuran perusahaan dapat memoderasi pengaruh leverage pada pengungkapan CSR

Perusahaan besar dengan kepemilikan asing mungkin akan melaksanakan tanggung jawab sosial yang lebih banyak dibandingkan dengan perusahaan kecil. Hal ini karena, perusahaan yang didalamnya terdapat investor asing akan melakukan pengungkapan tanggung jawab sosial, agar memperoleh legitimasi dari para investor asing yang dimiliki serta masyarakat sekitar. Pengungkapan akan lebih luas lagi apabila perusahaan besar memiliki tingkat sensitivitas tinggi pada lingkungan sekitarnya. Karena dengan melakukan pengungkapan CSR seluas-luasnya, akan meningkatkan citra yang baik di mata para investor asing maupun masyarakat. Dilihat dari urain tersebut, dapat disimpulkan hipotesis keenam yang diuji pada penelitian ini yaitu:

$\mathrm{H}_{6} \quad$ :Ukuran perusahaan dapat memoderasi pengaruh kepemilikan asing pada pengungkapan CSR

Berdasarkan paparan teori dan hipotesis diatas, maka kerangka konseptual pada penelitian ini dapat digambarkan sebagai berikut. 


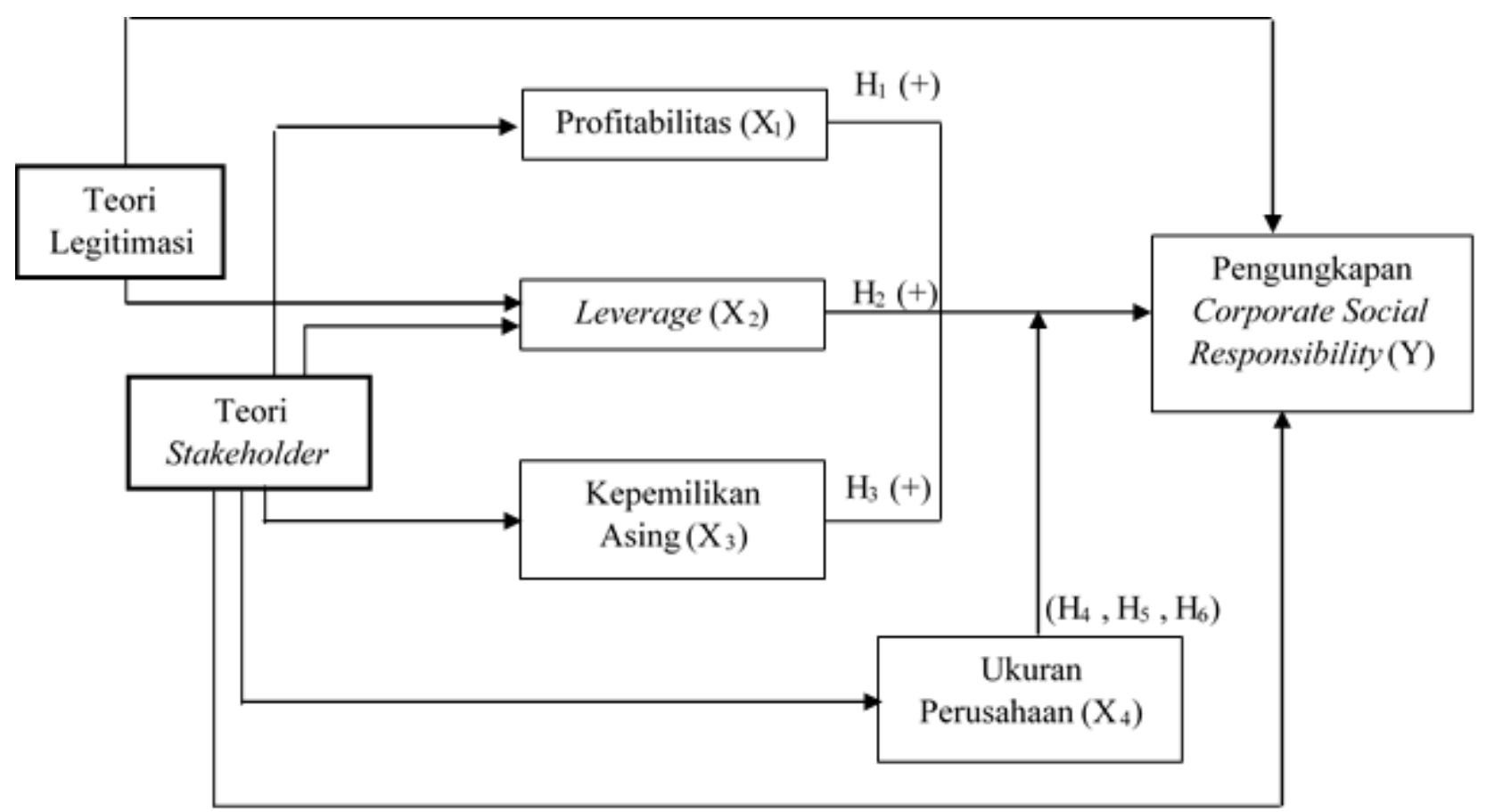

Gambar 1.

Kerangka Konseptual

\section{METODE PENELITIAN}

Penelitian menggunakan pendekatan kuantitatif berbentuk asosiatif, karena menguji dua variabel atau lebih (Sugiyono, 2014). Penelitian dilakukan pada perusahaan sektor consumer goods yang terdaftar di BEI periode 2012-2016 yang dapat diakses pada www.idx.co.id. Objek dari penelitian ini adalah pengungkapan corporate social responsibility yang diduga dipengaruhi oleh variabel profitabilitas, leverage, kepemilikan asing dan ukuran perusahaan.

Variabel independen dalam penelitian ini adalah profitabilitas (X1), leverage (X2) dan kepemilikan asing (X3). Variabel dependen dalam penelitian ini adalah pengungkapan CSR (Y). Variabel moderasi adalah variabel yang mempengaruhi baik memperkuat atau memperlemah hubungan antara variabel 
bebas atau independen dengan variabel terikat atau dependen (Sugiyono, 2014). Variabel moderasi dalam penelitian ini adalah ukuran perusahaan.

Pada penelitian ini, variabel profitabilitas diproksikan menggunakan Return On Asset (ROA), dimana ROA merupakan analisis keuangan yang dapat menunjukkan bagaimana kemampuan sebuah perusahaan dalam memperoleh laba atau keuntungan atas total aset yang dimilikinya. Rumus ROA yaitu laba bersih setelah pajak dibagi total aktiva. Variabel leverage diproksikan dengan Debt To Equity Ratio (DER) dengan rumus total kewajiban dibagi total ekuitas. Rasio ini akan menggambarkan sejauh mana hutang yang dimiliki oleh perusahaan bisa ditutupi dengan modal yang dimiliki oleh perusahaan. Variabel kepemilikan asing diproksikan menggunakan rasio persentase dari jumlah saham milik investor asing terhadap jumlah saham yang beredar. Variabel ukuran perusahaan diukur dengan total aset yang ditransformasikan dalam logaritma natural untuk menyamakan dengan variabel lain. Variabel pengungkapan CSR ini diproksikan menggunakan pedoman ISO 26000 yang terbagi menjadi 37 item pengungkapan sehingga memudahkan perusahaan untuk menetapkan kriteria pengungkapan CSR.

Populasi penelitian yaitu semua perusahaan kategori consumer goods yang terdaftar di Bursa Efek Indonesia tahun 2012-2016. Sampel didapatkan dengan menggunakan teknik purposive sampling. Penelitian ini menggunakan observasi non partisipan, yang berarti peneliti tidak terlibat langsung tetapi hanya sebagai pengamat. 
Kadek Nitya Devi Irmayanti dan Ni Putu Sri Harta Mimba. Pengaruh...

Jenis data penelitian yaitu data kuantitatif dengan sumber data berupa data sekunder yang merupakan data penelitian yang diperoleh dan dicatat oleh pihak lain. Teknik analisis data penelitian menggunakan uji interaksi moderasi atau moderated regression analysis (MRA). Berikut ini merupakan rumus yang digunakan dalam penelitian ini:

$Y=\alpha+\beta_{1} X_{1}+\beta_{2} X_{2}+\beta_{3} X_{3}+\beta_{4} X_{4}+\beta_{5} X_{1} \cdot X_{4}+\beta_{6} X_{2} \cdot X_{4}+\beta_{7} X_{3} \cdot X_{4}+\varepsilon$

Keterangan:

Y : Pengungkapan corporate social responsibility

$\alpha \quad$ : Konstanta

$\beta_{1}-\beta_{7} \quad$ : Koefisien regresi masing-masing faktor

$\mathrm{X}_{1} \quad$ : Profitabilitas

$\mathrm{X}_{2} \quad$ : Leverage

$\mathrm{X}_{3} \quad$ : Kepemilikan asing

$\mathrm{X}_{4}$ : Ukuran perusahaan

ci : Error term

\section{HASIL DAN PEMBAHASAN}

Wilayah penelitian dalam penelitian ini adalah perusahaan manufaktur subsektor consumer goods yang terdaftar di BEI tahun 2012-2016. Perusahaan consumer goods merupakan perusahaan yang memproduksi barang-barang konsumsi yang mencakup lima industri yaitu industri makanan dan minuman, rokok, farmasi, kosmetik dan peralatan rumah tangga. Berdasarkan kriteria yang digunakan dalam metode purposive sampling, maka diperoleh 7 perusahaan sampel yang memenuhi kriteria sampel yang dapat dilihat pada Tabel 1. 
ISSN: 2302-8556

E-Jurnal Akuntansi Universitas Udayana

Vol.23.3.Juni (2018): 1932-1954

Tabel 1.

Hasil Seleksi Sampel Penelitian

\begin{tabular}{clc}
\hline No. & \multicolumn{1}{c}{ Kriteria } & Akumulasi \\
\hline 1 & $\begin{array}{l}\text { Perusahaan consumer goods yang terdaftar di BEI } \\
\text { selama tahun pengamatan yaitu tahun 2012-2016. }\end{array}$ & 38 \\
\hline 2 & $\begin{array}{l}\text { Perusahaan consumer goods yang tidak } \\
\text { mempublikasikan laporan tahunan secara terus-menerus } \\
\text { selama periode tahun pengamatan yaitu tahun 2012- }\end{array}$ & \\
& 2016. & \\
\hline 3 & $\begin{array}{l}\text { Perusahaan yang tidak menyajikan pengungkapan CSR } \\
\text { dalam laporan tahunan secara terus-menerus selama } \\
\text { periode tahun pengamatan yaitu tahun 2012-2016. }\end{array}$ & $(2)$ \\
\hline 4 & $\begin{array}{l}\text { Perusahaan yang mengalami kerugian selama periode } \\
\text { pengamatan tahun 2012-2016. }\end{array}$ & $(11)$ \\
\hline 5 & $\begin{array}{l}\text { Perusahaan yang tidak memiliki proporsi kepemilikan } \\
\text { asing selama periode tahun pengamatan yaitu tahun }\end{array}$ \\
2012-2016 & Jumlah perusahaan yang dijadikan sampel \\
\hline
\end{tabular}

Sumber: Data diolah, 2017

Analisis statistik deskriptif pada penelitian ini disajikan Tabel 2.

Tabel 2.

Hasil Analisis Statistik Deskriptif

\begin{tabular}{lccccc}
\hline & N & Minimum & Maximum & Mean & Std. Deviation \\
\hline Pengungkapan CSR & 35 & 21,62 & 83,78 & 63,6291 & 17,71460 \\
Profitabilitas & 35 & 4,04 & 65,72 & 20,9791 & 15,55518 \\
Leverage & 35 & 15,02 & 302,86 & 108,9014 & 77,67046 \\
Kepemilikan Asing & 35 & 37,87 & 91,94 & 67,6109 & 17,94584 \\
Ukuran Perusahaan & 35 & 26,69 & 32,15 & 28,8014 & 1,64840 \\
Valid N (listwise) & 35 & & & & \\
\hline
\end{tabular}

Sumber: Data diolah, 2017

Pengungkapan CSR pada Tabel 2, yang dihitung berdasarkan pedoman

ISP 26000 memiliki nilai rata-rata variabel sebesar 63,6291 dengan standar deviasi sebesar 17,71460. Variabel CSR memiliki nilai terendah (minimum) sebesar 21,62 dan nilai tertinggi (maksimum) sebesar 83,78. Nilai standar deviasi lebih kecil dari nilai rata-rata yang berarti terjadi fluktuasi yang rendah pada variabel pengungkapan CSR.

Profitabilitas pada Tabel 2, diukur dengan proksi Return On Assets (ROA) memiliki nilai rata-rata sebesar 20,9791 dengan standar deviasi sebesar 15,55518. 
Kadek Nitya Devi Irmayanti dan Ni Putu Sri Harta Mimba. Pengaruh...

Variabel profitabilitas memiliki nilai terendah (minimum) sebesar 4,04 dimiliki dan nilai tertinggi (maksimum) sebesar 65,72. Nilai standar deviasi lebih kecil dari nilai rata-rata yang berarti terjadi fluktuasi yang rendah pada variabel profitabilitas.

Leverage pada Tabel 2, diukur dengan proksi Debt to Equity Ratio (DER) memiliki nilai rata-rata sebesar 108,9014 dengan standar deviasi sebesar 77,67046. Variabel leverage memiliki nilai terendah (minimum) sebesar 15,02 dan nilai tertinggi (maksimum) sebesar 302,86. Nilai standar deviasi lebih kecil dari nilai rata-rata yang berarti terjadi fluktuasi yang rendah pada variabel leverage.

Kepemilikan asing pada Tabel 2, diukur dengan rasio persentase jumlah saham yang dimiliki investor asing terhadap jumlah saham beredar memiliki nilai rata-rata variabel kepemilikan asing sebesar 67,6109 dengan standar deviasi sebesar 17,94584. Variabel kepemilikan asing memiliki nilai terendah (minimum) sebesar 37,87 dan nilai tertinggi (maksimum) sebesar 91,94. Nilai standar deviasi lebih kecil dari nilai rata-rata yang berarti terjadi fluktuasi yang rendah pada variabel kepemilikan asing.

Ukuran perusahaan pada Tabel 2, diukur dengan logaritma natural dari total aset memiliki nilai rata-rata variabel ukuran perusahaan sebesar 28,8014 dengan standar deviasi sebesar 1,64840. Variabel ukuran perusahaan memiliki nilai terendah (minimum) sebesar 26,69 dan nilai tertinggi (maksimum) sebesar 32,15. Nilai standar deviasi lebih kecil dari nilai rata-rata yang berarti terjadi fluktuasi yang rendah pada variabel ukuran perusahaan. 
Uji asumsi klasik pada penelitian ini menghasilkan uji normalitas, uji heteroskedastisitas dan uji autokorelasi. Uji normalitas bertujuan untuk mengetahui apakah residual dari model regresi yang dibuat berdistribusi normal atau tidak. Hasil uji normalitas dapat dilihat pada Tabel 3 sebagai berikut.

Tabel 3

Hasil Uji Normalitas One-Sample Kolmogorov-Smirnov Test

\begin{tabular}{lr}
\hline & Unstandardized Residual \\
$\mathrm{N}$ & 35 \\
Asymp. Sig. (2-tailed) & $118^{\mathrm{c}}$ \\
\hline Sumber: Data diolah, 2017 &
\end{tabular}

Berdasarkan hasil uji normalitas pada Tabel 3, diperoleh nilai Asymp. Sig. (2-tailed) sebesar 0,118 lebih besar dari 0,05. Hal ini menunjukkan bahwa data pada model regresi yang digunakan dalam penelitian telah berdistribusi normal.

Uji heteroskedastisitas, memiliki tujuan yaitu menguji model regresi apakah terjadi ketidaksamaan variance. Hasil uji heteroskedastisitas dapat dilihat pada Tabel 4 sebagai berikut.

Tabel 4.

Hasil Uji Heteroskedastisitas

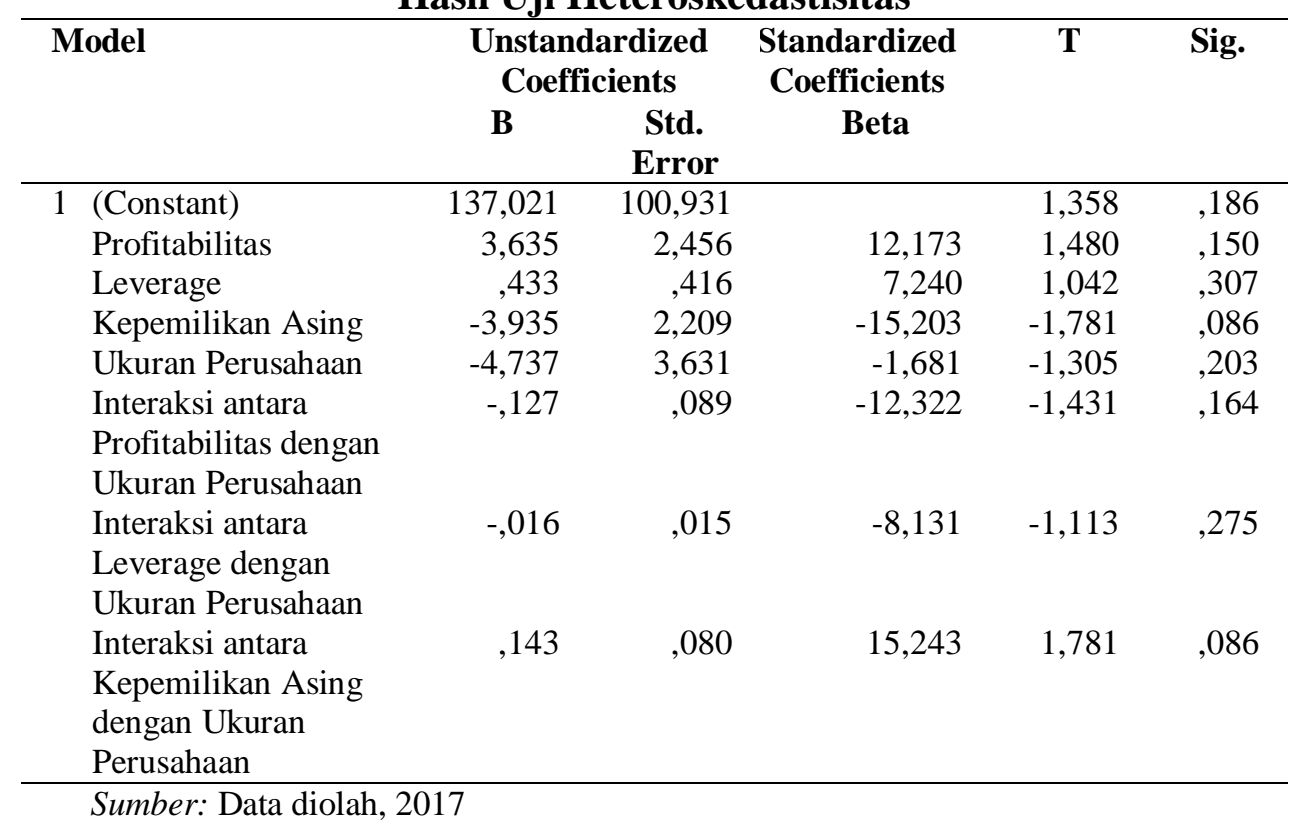


Kadek Nitya Devi Irmayanti dan Ni Putu Sri Harta Mimba. Pengaruh...

Tabel 4 menunjukkan bahwa nilai signifikansi dari masing-masing variabel sebesar 0,$150 ; 0,307 ; 0,086 ; 0,203 ; 0,164 ; 0,275 ; 0,086$ lebih besar dari tingkat signifikansi 0,05 ini berarti model regresi pada penelitian ini dapat dikatakan bebas dari heteroskedastisitas.

Uji autokorelasi bertujuan untuk mengetahui adanya korelasi atau hubungan yang terjadi diantara anggota-anggota dari serangkaian pengamatan yang tersusun dalam rangkaian waktu. Tabel 5 merupakan hasil uji autokolerasi dengan durbin-Watson.

Tabel 5.

Hasil Uji Autokorelasi

\begin{tabular}{|c|c|c|c|c|c|}
\hline Model & $876^{a}$ & $\begin{array}{c}\mathbf{R} \\
\text { Square } \\
768\end{array}$ & $\begin{array}{l}\text { Adjusted R } \\
\text { Square }\end{array}$ & $\begin{array}{r}\text { Std. Error of } \\
\text { the Estimate } \\
9,57249\end{array}$ & $\begin{array}{l}\text { Durbin- } \\
\text { Watson } \\
1794\end{array}$ \\
\hline & & & & & \\
\hline
\end{tabular}

Hasil uji autokolerasi dengan durbin-watson menunjukan nilai $\left(\mathrm{d}_{\mathrm{L}}<\mathrm{d}_{\mathrm{W}}<\right.$ $\left.\mathrm{d}_{\mathrm{U}}\right)=(1,034<1,794<1,967)$ maka tidak dapat ditarik kesimpulan mengenai ada tidaknya autokolerasi, sehingga dilakukan Uji Run Test untuk mengetahui ada tidaknya autokolerasi yang terlihat pada Tabel 6.

Tabel 6.

Hasil Uji Run Test

Unstandardized

Residual

Test Value ${ }^{\mathrm{a}}$

Asymp. Sig. (2-tailed)

2,41199

1,000

Sumber: Data diolah, 2017

Dilihat dari Tabel 6 diketahui bahwa nilai Asymp. Sig. (2-tailed) sebesar 1,000 lebih besar > dari 0,05 maka dapat disimpulkan bahwa tidak terdapat gejala atau masalah autokolerasi. 
ISSN: 2302-8556

E-Jurnal Akuntansi Universitas Udayana

Vol.23.3.Juni (2018): 1932-1954

Tabel 7.

Hasil Uji Moderated Regression Analysis (MRA)

\begin{tabular}{|c|c|c|c|c|c|c|}
\hline \multirow{2}{*}{\multicolumn{2}{|c|}{ Model }} & \multirow{2}{*}{\multicolumn{2}{|c|}{$\begin{array}{l}\text { Unstandardized } \\
\text { Coefficients }\end{array}$}} & \multirow{2}{*}{$\begin{array}{l}\text { Standardized } \\
\text { Coefficients }\end{array}$} & \multirow[t]{2}{*}{$\mathrm{T}$} & \multirow[t]{2}{*}{ Sig. } \\
\hline & & & & & & \\
\hline & & D & $\begin{array}{l}\text { Sta. } \\
\text { Error } \\
\end{array}$ & & & \\
\hline \multirow[t]{18}{*}{1} & (Constant) & 147,693 & 233,529 & & 632 & ,532 \\
\hline & Profitabilitas & $-10,418$ & 5,683 & $-9,148$ & $-1,833$ & ,078 \\
\hline & Leverage & 2,787 & ,963 & 12,221 & 2,896 & ,007 \\
\hline & Kepemilikan Asing & $-7,509$ & 5,116 & $-7,607$ & $-1,468$ & ,154 \\
\hline & Ukuran Perusahaan & $-2,619$ & 8,400 &,- 244 &,- 312 & ,758 \\
\hline & Interaksi antara & & & & & \\
\hline & $\begin{array}{l}\text { Profitabilitas dengan } \\
\text { Ukuran Perusahaan }\end{array}$ & ,357 & ,205 & 9,113 & 1,744 & ,092 \\
\hline & Interaksi antara & & & & & \\
\hline & Leverage dengan &,- 098 & ,034 & $-12,740$ & $-2,873$ & ,008 \\
\hline & Ukuran Perusahaan & & & & & \\
\hline & Interaksi antara & & & & & \\
\hline & Kepemilikan Asing & 263 & , 186 & 7,353 & 1,415 & , 169 \\
\hline & dengan Ukuran & & & & & \\
\hline & Perusahaan & & & & & \\
\hline & $\mathrm{R}^{2}$ & & & & & 0,768 \\
\hline & Adjusted $\mathrm{R}^{2}$ & & & & & 0,708 \\
\hline & F Statistik & & & & & 12,777 \\
\hline & F Signifikansi & & & & & 0,000 \\
\hline
\end{tabular}

Sumber: Data diolah, 2017

Berdasarkan Tabel 7, persamaan regresi yang terbentuk adalah sebagai berikut:

$Y=147,693-9,148 X_{1}+12,221 X_{2}-7,607 X_{3}-0,244 X_{4}+9,113 X_{1} X_{4}-$

$12,740 X_{2} X_{4}+7,353 X_{3} X_{4}+\varepsilon$

Uji kelayakan model (uji F) dilakukan untuk menguji signifikansi secara serempak atau bersama-sama semua variabel independen terhadap variabel dependen. Berdasarkan hasil analisis pada Tabel 7 dengan tingkat signifikan $(\alpha)$ sebesar 5 persen atau 0,05 menunjukkan nilai $\mathrm{F}$ hitung sebesar 12,777 dan nilai signifikansi $\mathrm{F}$ atau $p$-value sebesar 0,000 lebih kecil dari $\alpha=0,05$. Hal ini menunjukkan bahwa semua variabel independen yang diuji pada penelitian ini berpengaruh secara simultan pada variabel dependen. Jadi dapat disimpulkan bahwa model mampu layak digunakan. 
Kadek Nitya Devi Irmayanti dan Ni Putu Sri Harta Mimba. Pengaruh...

Uji $\mathrm{R}^{2}$ atau uji koefisien determinasi digunakan untuk mengukur seberapa jauh kemampuan model regresi dalam menerangkan kemampuan variasi variabel dependen. Pada Tabel 7 dapat dilihat nilai Adjusted $\mathrm{R}^{2}$ adalah 0,708 artinya bahwa 70,8\% variansi dari variabel dependen, yaitu pengungkapan CSR mampu dijelaskan oleh variansi-variabel independen sedangkan sisanya 29,2\% dijelaskan oleh faktor lain yang tidak dimasukkan ke dalam model.

Uji hipotesis (Uji t) menunjukkan pengaruh variabel independen secara individu terhadap variabel dependen. Kriteria pengambilan keputusan yaitu jika nilai signifikansi > 0,05 maka tidak ada pengaruh secara parsial variabel independen pada variabel dependen, dan sebaliknya jika nilai signifikansinya < 0,05 maka ada pengaruh secara parsial variabel independen pada variabel dependen.

Tabel 7 menunjukkan bahwa nilai sig uji t untuk variabel profitabilitas adalah 0,078 lebih besar dari 0,05 dimana koefisien regresinya negatif sebesar 9,148, sehingga $\mathrm{H}_{1}$ ditolak. Artinya, profitabilitas tidak berpengaruh pada pengungkapan CSR. Hasil dari penelitian ini tidak mampu mendukung teori bahwa perusahaan yang memiliki profit tinggi, maka pihak manajemen akan melakukan pengungkapan CSR yang lebih tinggi juga. Tinggi rendahnya profitabilitas perusahaan tidak terlalu berpengaruh terhadap pengungkapan CSR karena, pengungkapan CSR sekarang ini sudah menjadi hal yang wajib dilakukan setiap perusahaan sejak dikeluarkannya Peraturan Pemerintah Republik Indonesia Nomor 47 Tahun 2012 tentang Tanggung Jawab Sosial dan Lingkungan Perseroan Terbatas, menyatakan bahwa Perseroan yang kegiatan usahanya berkaitan dengan 
sumber daya alam diwajibkan untuk melaksanakan tanggung jawab sosial dan lingkungan. Hasil penelitian ini sejalan dengan beberapa penelitian sebelumnya yaitu Nur dan Denies (2012), Dermawan dan Deitiana (2014) serta Kusumawardani (2017). Nur dan Denies (2012) menyatakan ketika perusahaan memiliki laba yang tinggi, maka manajemen perusahaan menganggap tidak perlu lagi melaporkan hal-hal yang dapat mengganggu informasi mengenai keberhasilan keuangan perusahaan, namun sebaliknya saat tingkat profitabilitas rendah atau menurun, pihak perusahaan berharap bahwa pengguna laporan perusahan akan membaca "good news" dari kinerja lingkungan dan sosial yang telah dilakukan perusahaan.

Tabel 7 menunjukkan nilai sig uji t untuk variabel leverage adalah 0,007 lebih kecil dari 0,05 dengan nilai koefisien regresi positif yaitu 12,221. Sehingga dari hasil yang diperoleh maka hipotesis kedua $\left(\mathrm{H}_{2}\right)$ diterima. Artinya, leverage berpengaruh positif pada pengungkapan CSR. Sejalan dengan teori stakeholder, rasio leverage yang tinggi akan mengungkapan lebih banyak informasi, karena tanggung jawab perusahaan terhadap para stakeholder-nya seperti kreditur dan investor akan lebih besar untuk meningkatkan kepercayaan dan mempermudah dalam permodalannya. Tambahan informasi berupa pengungkapan CSR pada laporan tahunan perusahaan dapat menghilangkan keraguan pemegang obligasi terhadap hak mereka sebagai kreditur. Hasil penelitian ini sejalan dengan penelitian sebelumnya yang dilakukan oleh Yanti dan Budiasih (2016) yang menyatakan bahwa leverage berpengaruh positif terhadap pengungkapan CSR. 
Kadek Nitya Devi Irmayanti dan Ni Putu Sri Harta Mimba. Pengaruh...

Tabel 7 menunjukkan nilai sig uji t variabel kepemilikan asing adalah 0,154 lebih besar dari 0,05 dengan nilai koefisien regresi yaitu-7,607. Dari hasil tersebut maka hipotesis ketiga $\left(\mathrm{H}_{3}\right)$ ditolak. Artinya, kepemilikan asing tidak memiliki pengaruh pada pengungkapan CSR. Hasil penelitian ini sejalan dengan penelitian yang dilakukan oleh Rohmah (2015), Nugroho dan Yulianto (2015), Kusumawardani (2017) dan Urmila (2017) yaitu kepemilikan asing tidak berpengaruh pada pengungkapan CSR.

Hal ini dikarenakan kepemilikan asing tidak mampu memotivasi pihak manajemen perusahaan untuk melakukan pengungkapan CSR secara intensif, untuk memberikan manfaat atau memperoleh legitimasi dari para stakeholdernya, sehingga hal ini tidak dapat membuktikan berlakunya teori legitimasi dan stakeholder sebagai teori yang mendukung dan melandasi penelitian ini. Selain itu Urmila (2017) menyatakan kurangnya kesadaran dari pihak asing yang menanamkan sahamnya pada perusahaan yang terdaftar di BEI terhadap segala aspek yang mencakup aspek lingkungan dan sosial sebagai suatu isu penting yang harus diungkapkan perusahaan pada laporan tahunannya.

Tabel 7 menunjukkan nilai sig uji t untuk interaksi variabel profitabilitas dengan variabel ukuran perusahaan adalah 0,092 lebih besar dari 0,05 dengan nilai koefisien regresi sebesar 9,113, maka hipotesis keempat $\left(\mathrm{H}_{4}\right)$ ditolak. Artinya, ukuran perusahaan tidak memoderasi pengaruh profitabilitas pada pengungkapan CSR. Ukuran perusahaan tidak mampu memoderasi pengaruh profitabilitas pada pengungkapan CSR karena ketika perusahaan dengan tingkat laba yang tinggi, pihak manajemen perusahaan menganggap tidak perlu lagi melaporkan hal-hal 
yang dapat mengganggu informasi mengenai keberhasilan keuangan perusahaan, tetapi hal tersebut dapat dilakukan pada saat tingkat profitabilitas rendah. Ukuran perusahaan baik perusahaan besar maupun perusahaan kecil pasti menginginkan dukungan dari para stakeholder-nya untuk menjaga kelangsungan perusahaannya.

Tabel 7 menunjukkan nilai sig uji t untuk interaksi variabel leverage dengan variabel ukuran perusahaan adalah 0,008 lebih kecil dari 0,05 dengan nilai koefisien regresi yaitu $-12,740$, maka hipotesis kelima $\left(\mathrm{H}_{5}\right)$ diterima. Nilai koefisien regresi negatif, berarti ukuran perusahaan memperlemah pengaruh leverage pada pengungkapan CSR. Hal ini dikarenakan ukuran perusahaan yang besar atau kecil belum bisa menjamin pengungkapan CSR yang luas, karena perusahaaan besar atau kecil belum berani melakukan pengungkapan CSR secara luas sebelum hutang atau kewajibannya terpenuhi untuk menekan biaya yang akan dikeluarkan dengan adanya pengungkapan CSR tersebut (Setiadewi dan Purbawangsa, 2014).

Tabel 7 menunjukkan nilai sig uji t untuk interaksi variabel kepemilikan asing dengan variabel ukuran perusahaan adalah 0,169 lebih besar dari 0,05 dengan nilai koefisien regresi yaitu 7,353 maka dapat dikatakan bahwa hipotesis keenam $\left(\mathrm{H}_{6}\right)$ ditolak. Artinya, ukuran perusahaan tidak mampu memoderasi pengaruh kepemilikan asing pada pengungkapan CSR. Hal ini sesuai dengan teori stakeholder, yaitu kelangsungan hidup perusahaan bergantung pada dukungan stakeholder salah satunya yaitu investor asing. Investor asing cenderung peduli dengan isu lingkungan dan isu sosial, maka dari itu ukuran perusahaan baik perusahaan besar maupun perusahaan kecil pasti menginginkan dukungan dari 
Kadek Nitya Devi Irmayanti dan Ni Putu Sri Harta Mimba. Pengaruh...

para stakeholder-nya untuk menjaga kelangsungan hidup jangka panjang perusahaannya. Sehingga perusahaan akan melakukan pengungkapan CSR untuk memperoleh dukungan serta mempermudah dalam permodalannya tanpa memandang ukuran perusahaannya baik besar ataupun kecil.

\section{SIMPULAN}

Berdasarkan penelitian yang dilakukan, maka dapat disimpulkan bahwa profitabilitas dan kepemilikan asing tidak berpengaruh pada pengungkapan CSR. Ukuran perusahaan tidak mampu memoderasi pengaruh profitabilitas pada pengungkapan CSR dan pengaruh kepemilikan asing pada pengungkapan CSR. Penelitian ini juga menyimpulkan bahwa leverage berpengaruh positif pada pengungkapan CSR, ini berarti semakin tinggi tingkat leverage suatu perusahaan maka semakin tinggi pula tingkat pengungkapan CSR yang dilakukan. Selain itu, ukuran perusahaan mampu memoderasi (memperlemah) pengaruh leverage pada pengungkapan CSR. Hal ini dikarenakan, perusahaan besar maupun kecil belum berani melakukan pengungkapan CSR secara luas sebelum hutang atau kewajibannya terpenuhi untuk menekan biaya yang akan dikeluarkan dengan adanya pengungkapan CSR tersebut.

Berdasarkan simpulan yang telah disampaikan, maka saran yang dapat diberikan adalah sebagai berikut: Bagi perusahaan, penelitian ini berkontribusi khususnya pada perusahaan consumer goods untuk mengetahui faktor-faktor yang mempengaruhi pengungkapan CSR. Sehingga, perusahaan consumer goods sebaiknya mengungkapan seluruh aktivitas tanggung jawab sosial yang dilakukan 
perusahaan pada laporan tahunan (annual report) secara lebih luas dan banyak untuk mendapatkan legitimasi dari para stakeholder-nya.

Bagi investor, sebaiknya jika ingin menilai sebuah perusahaan untuk menanamkan modal, harus melihat dari segala aspek tidak hanya dari profit yang dihasilkan perusahaan saja, namun juga harus melihat bagaimana tanggung jawab sosial yang dilakukan oleh perusahaan terhadap lingkungannya sebagai salah satu bentuk pertanggungjawaban bagi stakeholder-nya. Bagi peneliti selanjutnya, diharapkan untuk meneliti pengungkapan corporate social responsibility yang bersifat wajib atau mandatory pada perusahaan manufaktur sektor lainnya, serta menambahkan variabel independen maupun variabel pemoderasi lainnya yang dapat digunakan untuk mendeteksi pengungkapan tanggung jawab sosial perusahaan.

\section{REFERENSI}

Aghashahi, Betsabeh, Siti Zaleha Abd Rasid, Majid Sarli dan Abdollah Ah Mand. 2013. Corporate Social Responsibility Reporting of Food Industry Major Players. Interdisciplinary Journal of Contemporary Research in Business, 5 (2), pp.751-761.

Ansori, Ema Rosyidah. 2014. Analisis Faktor-faktor yang Mempengaruhi Perataan Laba Pada Perusahaan Manufaktur yang Terdaftar di BEI. Jurnal Ilmu \& Riset Akuntansi, 3 (11), hal.1-25.

Dewi, Sepian dan Agung Suaryana. 2015. Pengaruh Profitabilitas dan Kepemilikan Asing Pada Pengungkapan Corporate Social Responsibility. E-Jurnal Akuntansi Universitas Udayana, 13 (1), hal.84-98.

Djackman, Chaerul D. dan N. Machmud. 2008. Pengaruh Struktur Kepemilikan terhadap Luas Pengungkapan Tanggung Jawab Sosial (CSR Disclosure) pada Laporan Tahunan Perusahaan: Studi Empiris pda Perusahaan Publik yang Tercatat di Bursa Efek Indonesia Tahun 2006. Simposium Nasional Akuntansi XI. Pontianak. 
Gray, R., Owen, D. dan Maunders, K. 1987. Corporate Social Reporting: Accounting and Accountability, Prentice-Hall, London.

Heinze, D. C. 1976. Financial Correlates Of A Social Involvement Measure. Akron Business and Economics Review, 7 (1), pp.48-51.

Ikatan Akuntansi Indonesia (IAI). 2013. Penyajian Laporan Keuangan. Pernyataan Standar Akuntansi Keuangan No. 1. Jakarta: DSAK-IAI

ISO. 2009. Draf Internasional Standar ISO 26000 : Guidance on Social Responsibility.http://isotc.iso.org/livelink/livelink?func=ll\&objId=393583 7\&objAction=brows e\&sort=name. Diakses tanggal 25 September 2017

Kusumawardani, Ira dan I Putu Sudana. 2017. Faktor-faktor yang Mempengaruhi Pengungkapan Corporate Social Responsibility. E-Jurnal Akuntansi Universitas Udayana, 19 (1), hal.741-770.

Kusumawardani, Ira. 2017. Faktor-faktor yang Mempengaruhi Pengungkapan Corporate Social Responsibility. Skripsi Jurusan Akuntansi pada Fakultas Ekonomi dan Bisnis Universitas Udayana, Bali.

Maulida, Dinda. 2013. Pengaruh Kepemilikan Asing, Afiliasi Asing dan Proyek Pemerintah Terhadap Luas Pengungkapan Tanggung Jawab Sosial Perusahaan (Studi pada Perusahaan yang Terdaftar di BEI Tahun 2011). Skripsi Jurusan Akuntansi pada Fakultas Ekonomika dan Bisnis Universitas Diponegoro, Semarang.

Nugroho, Mirza Nurdin dan Agung Yulianto. 2015. Pengaruh Profitabilitas dan Mekanisme Corporate Governance Terhadap Pengungkapan CSR Perusahaan Terdaftar JII 2011-2013. Accounting Analysis Journal pada Fakultas Ekonomi Universitas Negeri Semarang, 4 (1), hal.1-12.

Peraturan Pemerintah Nomor 47 Tahun 2012 Tanggung Jawab Sosial dan Lingkungan Perseroan Terbatas. 4 April 2012. Lembaran Negara Republik Indonesia Tahun 2012 Nomor 89. Jakarta.

Prihatiningtias, Yeney Widya dan Nadia Dayanti. 2014. Corporate Social Responsibility Disclosure and Firm Financial Performane in Mining and Natural Resources Industry. The International Journal of Accounting and Business Society, 22 (1), pp.35-58.

Putra, Anggara Satria. 2015. Pengaruh Corporate Social Responsibility Terhadap Profitabilitas Perusahaan Studi Empiris pada Perusahaan Sektor Industri Barang Konsumsi yang terdaftar di Bursa Efek Indonesia Tahun 20102013). Jurnal Nominal, 4 (2), hal.91-110. 
Sudjana, Ni Luh Asri Suryaputri. 2017. Faktor-faktor yang Mempengaruhi Pengungkapan CSR dengan Profile Perusahaan Sebagai Variabel Pemoderasi Pada Perusahaan Manufaktur yang Terdaftar di BEI. Skripsi Sarjana Jurusan Akuntansi Fakultas Ekonomi dan Bisnis Universitas Udayana, Bali.

Sugiyono. 2014. Metode Penelitian Kuantitatif, Kualitatif, dan Kombinasi (Mixed Methods). Bandung: Alfabeta.

Undang-Undang No. 25 Tahun 2007 Penanaman Modal. 26 April 2007. Lembaran Negara Republik Indonesia Tahun 2007 Nomor 67. Jakarta

Undang-Undang No. 32 Tahun 2009 Perlindungan dan Pengelolaan Lingkungan Hidup. 3 Oktober 2009. Lembaran Negara Republik Indonesia Tahun 2009 Nomor 14. Jakarta

Undang-Undang No. 40 Tahun 2007 Perseroan Terbatas (PT). 16 Agustus 2007. Lembaran Negara Republik Indonesia Tahun 2007 Nomor 106 . Jakarta

Urmila, Ni Made Diah. 2017. Tipe Perusahaan Sebagai Pemoderasi Pengaruh Ukuran Perusahaan, Profitabilitas, dan Kepemilikan Asing Pada Pengungkapan Corporate Social Responsibility Di Perusahaan Manufaktur yang Terdaftar Di Bursa Efek Indonesia. Skripsi Sarjana Jurusan Akuntansi Fakultas Ekonomi dan Bisnis Universitas Udayana, Bali.

World Bank Corporate Social Responsibility Definition. http:://www.ifc.org/ifcext/economics.nsf/content/csr-intropage. Diakses 20 September 2017.

Yanti, Ni Kadek Ayu Giri dan I Gusti Ayu Budiasih. 2016. Pengaruh Profitabilitas, Leverage, dan Ukuran Perusahaan pada Pengungkapan Corporate Social Responsibility. E-Jurnal Akuntansi Universitas Udayana, 17 (3), pp.1752-1779

Yuliawati dan Sukirman. 2015. Faktor-Faktor yang Mempengaruhi Pengungkapan Corporate Social Responsibility. Accounting Analysis Journal, 4 (4), hal.1-9. 